\title{
SEMIOTICS IN THE ETHNIC CULTURE OF BULGARIA AND MACEDONIA
}

\author{
(C) Nargilya A. Gadzhieva, Diana Sh. Asulova, Yarhanum R. Yarova
}

\author{
Dagestan State University of National Economy, \\ Dagestan State Pedagogical University, Makhachkala, \\ Dagestan Republic, Russian Federation \\ science-almanac@mail.ru
}

Semiotics began as an academic study of the meaning of words (linguistics), switched to the study of the people`s behaviour (anthropology and psychology), then to the study of culture and society (philosophy and sociology), after which it switched to assisting in the analysis of cultural products. Semiotics has recently become a methodology for the study and analysis of national costumes, everyday clothes, food, consumer behaviour, etc. In the value picture of the world of a certain ethnos there are the most significant cultural and semantic dominants for it, defined in cultural studies as concepts. The main object of the study of semiotics of culture is the hierarchy of sign systems of both existing and historical culture, as well as the relations between these sign systems. The study of the cultural space is carried out through the study of ethnoculture, the main focus is on the consideration of semiotics of culture and ethnocultures of the Bulgarian and Macedonian peoples on the examples of national clothing, features of national cuisine, with a focus on their social significance and interrelationship.

Key words: semiotics, the Bulgarians, the Macedonians, traditions, ethical culture, history.

\section{[Н.А. Гаджиева, Д.Ш. Асулова, Я.Р. Ярова Семиотика в этнической культуре Болгарии и Македонии]}

Семиотика начиналась как академическое исследование значения слов (лингвистика), перешла к изучению поведения людей (антропология и психология), затем в исследование культуры и общества (философия и социология), после чего перешла к оказанию помощи в анализе культурных продуктов. В последнее время семиотика стала методологией для исследования и анализа национальных костюмов, повседневной одежды, еды, поведения потребителей и т. п. В ценностной картине мира определённого этноса существуют наиболее значимые для него культурные и смысловые доминанты, определяемые в культурологии в качестве концепций. Основным объектом исследования семиотики культуры является иерархия знаковых систем как существующей, так и исторической культуры, и также соотношений между этими знаковыми системами. Исследование пространства культуры осуществляется через изучение этнокультуры, основное внимание уделяется рассмотрению семиотики культуры и этнокультур болгарского и македонского народов на примерах национальной одежды, особенностей национальной кухни с акцентом на их социальную значимость и взаимосвязь.

Ключевые слова: семиотика, болгары, македонцы, традиции, этическая культура, история.

Nargilya A. Gadzhieva - Ph.D. in Philology, Associate Professor, Dagestan State University of National Economy, Makhachkala, Dagestan Republic, Russian Federation.

Diana Sh. Asulova - Ph.D. in Philology, Associate Professor, Dagestan State Pedagogical University, Makhachkala, Dagestan Republic, Russian Federation.

Yarhanum R. Yarova - Ph.D. in Philology, Associate Professor, Dagestan State Pedagogical University, Makhachkala, Dagestan Republic, Russian Federation.

Гаджиева Наргиля Азадиевна - кандидат филологических наук, доцент, Дагестанский государственный университет народного хозяйства, г. Махачкала, Республика Дагестан, Российская Федерация.

Асулова Диана Шамильевна - кандидат филологических наук, доцент, Дагестанский государственный педагогический университет, г. Махачкала, Республика Дагестан, Российская Федерация.

Ярова Ярханум Ризаевна - кандидат филологических наук, доцент, Дагестанский государственный педагогический университет, г. Махачкала, Республика Дагестан, Российская Федерация. 
Ethnoculture is considered to be "a group of people or a community with an unchanged culture and ethnicity." For the existence of ethnoculture there must be a continuous and immiscible line that supports its culture in the form of philosophy, values, traditions, art, etc. Along with the seemingly ordinary but noticeably diverse national costumes, ways of cooking, rituals, etc. Bulgarian and Macedonian villages are the guardians of the spirit and traditions of the people, their centuries-old traditions, folklore and wisdom. In rural areas of these countries, traditional authentic dishes, folklore songs, folk dances, regional legends and fairy tales prevail. Many villages have preserved authentic appearance, which allows you to learn more about local customs and traditions. In today's world, it is increasingly clear that culture is central in all types of contexts. This is not the context itself, which changes the use of language or the pattern of behaviour between persons, but the meaning associated with this context, which is determined by culture. Thus, an extensive layer of folklore tradition - legends, traditions, and other mystical practices "record communicative norms, form feelings of community ownership (a dedicatory role), unity on the basis of general experience inaccessible to strangers (a consolidating role), remove or attract visitors (a management function)." Mystical folklore acts and is read within the community, mediating group processes within the ethnos [4, $p$. 146].

Ethnoculture can be a part of culture, for example, the regions of Bulgaria and Macedonia. In the value picture of the world of a certain ethnic group, there are the most significant cultural and semantic dominants for it, defined in cultural studies as concepts. The main object of the study of semiotics of culture is the hierarchy of sign systems of culture, between existing and historical sign systems.

Folk costumes, like countries, have a centuries-old tradition; they are a part of material culture and a branch of folk art. Their formation reflects various historical, social, economic and cultural events. Different cultural influences over the centuries in different historical eras are reflected in national clothing, created on the basis of folk knowledge, adapted to the national essence and lifestyle, improved taking into account folk aesthetic considerations. In addition to cultural and historical conditions and people's creative spirit in the formation and modelling of costumes, both geographical and environmental conditions are also important. Clothing non-verbally convey the meanings of people and groups, this is the language of signs and symbols, which "reflects culture, psyche and way of thinking. Clothing performs two functions: materialistic (as a material thing), and symbolic (as a sign). Materialistic and symbolic characteristics of clothing focus not only on what appearance means, but rather on how appearance means. One aspect of various countries of the world is that each of them retains its national identity. In the age of globalization and technology, the world has become one, but there are things like national clothing and food that continue to make each country unique. Each of the different components of the national costume is unique, but the effect comes from the entire ensemble, wearing only one part of the costume does not make a person either the Bulgarian or the Macedonian. Semiotics is the study of meaning-making of signs and symbols. Semiotic analysis focuses on the value of the sender and the recipient of signs. The message is sent through channels that use style and manner of communication, clothing codes (colour, function, etc.). "The visual symbol is what we perceive, that is, visible to the eye, which is translated by the brain and represents something else." The national costume reflects the symbols of the people`s culture [2, pp. 74-77].

For example, the culture of Bulgaria is based on the community. In bad times, the nation unites and remembers that the family is the support and the source of support. In good times, the Bulgarians wear neatly ironed folk clothes, known as nosiya, take hands in a dynamic linear dance called horo, and celebrate in a demonstration of unity, with an abundant amount of cheese, sausage, brandy and music. F. Manjapane considers that the 
festive table becomes a way to position yourself with a group to include all humanity in the idea of a community that is simultaneously political (I eat as well as my community), ethical (my community is properly fed), and even religious (humanity should eat as well as my community) [8, pp. 16-20].

The Bulgarians are proud to belong to the nation that has survived the rule of the Ottoman Empire, wars, famine, economic difficulties, they respect their culture and demonstrate this with respect for national clothes, among other things. They wear nosiya with a great sense of pride. Folk clothing serves as a key to personal history. Its intricate patterns on the sleeves as signs show whether a woman is married or single, and shoes of men`s nosiya are a sure sign of the man`s distinction (a farmer or a warrior). And although nosiya is no longer everyday clothes, in Bulgaria there are dozens of annual festivals, for example: the first day of spring, autumn harvest, New Year, etc.

Whenever the holiday includes folk dress, you can expect that the bagpipes orchestra will perform Biala Rosa and Boriano, Boryanke. This is followed by a long series of dancers firmly holding their hands performing horo, which sometimes goes round the whole quarter. Anyone can join, regardless of age. National leather shoes putting on with nosiya allow you to dance all the night.

Bulgarian folk clothing samples vary by region. There are seven different folklore districts in Bulgaria. Northern Bulgaria, Trakia, Shopljuk, Dobruja, Macedonia, Strandja and Rhodope, which have their own traditional songs and dances and appropriate folk clothes. Each article of folk clothing consists of several main components. For women, this is a headdress decorated with roses or gold coins, and a dress (nosiya), which is most often below the knee. The women's nosiya has two embroidered aprons (one behind and one in front), symbolizing the role of a woman as a housewife and a worker leading the entire economy. Aprons are fastened with a belt made of silver, bronze or fabric, such as silk or flax.

Men's folk clothing consists of a tall fur hat, a white shirt that emphasizes character decency, poturi pants, an embroidered vest and a wide red belt. The belt resembles the Bulgarian freedom fighters of the 18th century, when it was used to carry weapons such as daggers and knives. In both men's and women's folk clothes, shoes differ. Women wear "tsarvuli" leather slippers, which are suitable for dirty, uneven terrain. Sometimes you can see men in tsarvuli, since shoes are asexual and versatile, but they also wear tall boots that can withstand long days of pilgrimage, hiking, or even battle. Boots symbolize the role of a man as a defender and a soldier, and leather tsarvuli mean that the man performs agricultural work near the house. In northern Bulgaria, locals wear tsarvuli as everyday shoes, as they care for their cattle.

You can always find out by nosiya where the Bulgarian comes from. Residents of Tracia pay great attention to embroidery of the women's front apron and shirt sleeves. If a woman from the Danube region, her belt will be tied around the waist several times, and the emphasis of the pattern will be on the back apron. In the southern and southwestern regions of Bulgaria, the front apron of the women's nosiya is one-colour, red or black. In the Rhodope region, women have only one apron instead of two. Rhodope women tend to choose pale colours, such as a yellow-orange hue or green as grass, to demonstrate their connection with nature.

In addition, the embroidery signs of the dress indicate the marital status of the woman. If the braided pattern is simple and in the form of squares, then she is single. The triangles on the lady's apron tell us about engagement. If a woman is married, her nosiya will consist of four triangles. The main difference is that a single woman will wear a simple dress with a smaller quantity of patterns and often wear a flower behind her ear, which she will give to her beloved. A married woman will be much more decorated, symbolizing her higher status in society [12]. 
The Macedonian national costume is an interesting combination of elements of the tradition of the ancient Slavs, Ancient Greece, Byzantine civilization, Turkish-eastern elements, up to the last Western trends.

National costumes of Macedonia differ depending on the region of Skopska Blatija, Skopska Crna Gora, Upper Polog, Lower Polog, Prilepsko-Bitol Plain, Upper Prespa, Lower Prespa, Ohrid Plain, Struga, Drimkol, Malesia, Mariovo, Ovche Pole, Malesevo etc. and representing the expression of the collective, aesthetic and psychological sentiments of the Macedonian people. They also reflect economic and cultural developments. The Macedonian people care about the preservation of heritage, as evidenced by the rich variety of cultural events and festivals held in the country. Starting from the Balkan Folklore Festival, one of the most intriguing and incendiary festivals that Macedonia can offer. The festival is dedicated to the cultural and social history of the country, in which up to 50,000 people take part, getting acquainted and transmitting stories from generation to generation with the help of dances, songs, rites and poetry. Lovers of the history of Macedonia can also admire the traditional costumes presented at the exhibition [13].

In addition to cultural and historical conditions and the creative spirit of people in the formation and modelling of costumes, geographical and environmental conditions are also very important in Macedonia. The culture of highlanders, mainly engaged in agriculture, the culture of field people, focused mainly on agriculture stand out in special specific forms, both material and spiritual. In many areas, these two cultures are intertwined, creating various forms of complex clothing culture, as well as in general folk life as a whole. All these stakeholders who participated in the creation of costumes in Macedonia and in the creation of traditional forms of folk clothing were important factors for the final formation of various and typical forms of folk costumes and folk clothing in general. For all its richness, expressed in the number and variety of clothes, its decor, ornamental composition and colour scheme, costumes reached us through the surviving images used in the 19th century and in the first decades of the 20th century with the predominance of red-black, and white colours, with yellow and green as secondary accents [11].

The main subject of Macedonia's national costume is a shirt koshula made of dense flax or hemp with embroidery in front, on the hem and sleeves. On top of the shirt, women wear a long vest made of coarse dense material of dense wool called elek. Apron and belt are also considered to be signs of clothing. In solemn cases, the belt is decorated with pompoms.

The men's costume, in addition to stockings and shoes called opanci, consists of a shirt with a very wide lower part, flax trousers narrow in the lower part and wide in the upper part, and a wide waistband holding the shirt at the waist, also a leather belt.

Through a national costume the territorial origin, marital status and social relationships of generations of different age reveal. On the long way of development, in continuous process of support of old traditions by inclusion of elements of national taste and understanding, costumes are formed as a special ethnic differentiated folklore branch. They represent difficult shaped parts in which separate articles of clothing, both in terms of a decor, and on colour and an ornament are harmoniously combined. The general composition of a costume is adapted to its practical functions, but also serves for satisfaction of aesthetic representations of the creator. Thus, each costume represents the product of irregular shape from the textile material painted in different colours and tones, decorated with an embroidery or fabric of various ornamental motives and complemented with various ornaments. A variety of costumes can be met in the territory of Bulgaria and in the most part of the territory of Macedonia in which there are certain features. In each region of the countries there was a costume which differed from the neighbouring region in functional and aesthetic characteristics. The variety of costumes was affected by various migration movements which happened in various landscape units of the countries in the 
past. As these movements taking into account specific political, economic and social conditions were more intensive and stronger, the variety of costumes was more expressed. Richness of costumes, differences in individual clothes and also in national clothes are expressed both in stylistic composition of a costume, and in quantity and a variety of clothes and a decor. Researches of ethnoculture reveal "the idea of human consciousness, unity with ethnocultural, social values and traditions that defines the nature of evolution of spiritual culture, cultural connection between generations" [5].

Cuisine, unlike national costumes kept in museums and/or worn for celebrations and rituals, is an area of everyday life. The influence of the long dominance of the Ottoman Empire and the most numerous minority groups living in the territories of two countries is evident in the dishes of Bulgarian and Macedonian cuisine with such dishes as sarma (stuffed grape-vine or cabbage leaves), mousaka, ratatouille, Turkish borek, and bakery food of eastern cuisine such as pakhlava, tulumba, of course, Turkish coffee, etc. [9, pp. 22-28].

From the point of view of a person's biological nature, food, noted A.G. Maslow, is included in the list of basic human needs and, depending on the situation, the importance of seven basic human needs: air, water, food, shelter, safety, sleep, clothing (in some cases) can be lower or higher [1, p. 52].

Food is not only a substance for survival and nutrition, but also a part of the sign system, since it is involved in the processes of designation and interpretation. Taste goes beyond individual perception, encompassing an intersubjective and collective level. If, on the one hand, the measurement of taste depends on biological and/or physiological characteristics and, therefore, individual components, on the other hand, it seems that the change in taste is socially and culturally deterministic, since it is based on intersubjectively defined assessment models. Thus, such a type of human activity as cooking, except for taste sensations, as Lévi-Strauss points out in his "Mythological Studies," is a key guideline for analysing symbolism "...food is a vivid manifestation of the "interaction of nature and culture" the author noted [7, p. 387].

It is "natural" for all people and animals to consume food, but the methods of consumption used by people are a distinctive part of human culture. E. Leach notes "cooking...is a universal means by which nature is transformed into culture" [6, p. 34].

If cooking is considered as a structured process that includes substances, practices, habits, cooking techniques, consumption techniques, etc. that are a part of the meaning difference system, then food is just one example of culture and its code variability; nutrition does not simply coincide with the needs or physiological processes and processes of perception, it concerns all types of activities, discourses and images related to it. Based on this and other works on the study of national cuisine, "the direct connection between various signs, texts, discourses and practices" related to the gastronomy of the countries of the Black Sea basin is visible, indicating the importance of a semiotic approach in the study [10].

Each culture establishes basic values and principles that serve as the basis of morality. The theory of relativism claims that so it is now, it has always been and will be. The theory also states that not only different cultures hold different views, but it is also impossible for a single set of principles for the whole world to ever exist, because there are no universal principles that can be applied to all peoples. The theory also states that all such reflections on principles are just a reflection of a certain culture. Thus, in every culture there are and always will be distinctive features of culture manifested in national principles. 


\section{Лumepamypa}

1. Маслоу А.Г. Мотивация и личность: (пер. с англ.), СПб: Издательский дом "Питер", 2009. с. 52.

2. Петрова Ю.А. Знаково-символические системы как часть семиотических систем в молодежных субкультурах // Гуманитарные и социальноэкономические науки. 2019. № 3 (106). с. 74-77.

3. Петрова Ю.А. Особенности лингвокультурологического подхода к исследованию ценностей молодежной субкультуры // Экономические и гуманитарные исследования регионов. 2012. № 3. с.159-165.

4. Петрова Ю.А. Репрезентация ценностей молодежной субкультуры в ценностно - смысловом пространстве языка, диссертация на соискание ученой степени кандидата философрских наук. Ростов-на-Дону: ЮФУ, 2012. с. 189.

5. Adzhemian M., Petrova $Y u$. Features of cultural and religious traditions of the Armenia people. // Научный альманах стран Причерноморья. 2020. № 3. URL: https://science-almanac.ru/documents/336/2020-03-13-Adzhemian.pdf. (дата обращения: 29.12.20).

6. Leach, E., Lévi-Strauss, Cl. Modern Masters, London: Fontana, p. 34, 1970,127 p.

7. Lévi-Strauss $\mathrm{Cl}$. The Raw and the Cooked. Introduction to a Science of Mythology Volume 1, by Jonathan Cape, London, 1970, 387p

8. Manjapane F. Feast with a Stranger. Semiotics of Culinary Film, World Congress of SemioticsSofia. September, New Bulgarian University, 2014, c. 16-20.

9. Ostapuschenko A., Petrova Yu. Hospitality of the peoples of the North Caucasus as one of the North Caucasus as one of the elements of ethic culture // Научный альманах стран Причерноморья. 2019. № 4 (20). с. 22-28.

10. Stano S. Semiotics of Food. In: Trifonas P. (eds) International Handbook of Semiotics. Springer, Dordrecht, 2015. URL: https://doi.org/10.1007/978-94-0179404-6_30. (дата обращения: 28.12.20).

11.[Электронный ресурc], URL: https://folkcostume.blogspot.com/ Folk Costume \& Embroidery, posted by Roman K., December 19, 2020. (дата обращения: 28.12.20).

12.[Электронный ресурc], URL: https://matadornetwork.com/read/bulgarian-folkdress/ Bulgaria's folk dress is more than a beautiful garment. It displays personal history, posted by Aleksandrova D., Jul 28, 2020. (дата обращения: 19.12.20).

13.[Электронный ресурc], URL: https://theculturetrip.com/. The 10 Best Festivals in Macedonia, posted by The Culture Trip Ltd. (дата обращения: 23.12.20).

\section{References}

1. Maslow A.G. Motivatsiia i lichnost: (per. s angl.), SPb: Izdatelskii dom "Piter". [Motivation and personality: (translated from English), Saint Petersburg: Publishing House "Piter"], 2009. 52 p. (in Russian).

2. Petrova Yu.A. Znakovo-simvolicheskie sistemy kak chast semioticheskikh sistem v molodezhnykh subkulturakh. Gumanitarnye i sotsialno-ekonomicheskie nauki. [Symbolic systems as a part of semiotic systems in youth subcultures. Humanitarian and socio-economic sciences]. 2019. No. 3 (106). pp. 74-77 (in Russian).

3. Petrova Yu.A. Osobennosti lingvokulturologicheskogo podkhoda $k$ issledovaniiu tsennostei molodezhnoi subkultury. Ekonomicheskie i gumanitarnye issledovaniia regionov. [Features of a linguo-culturological approach to the study of the values of 
the youth subculture. Economic and humanitarian studies of regions]. 2012. No. 3. pp. 159-165 (in Russian).

4. Petrova Yu.A. Reprezentatsiia tsennostei molodezhnoi subkultury $v$ tsennostno smyslovom prostranstve iazyka, dissertatsiia na soiskanie uchenoi stepeni kandidata filosofskikh nauk. Rostov-na-Donu: YuFU. [Representation of the values of the youth subculture in the axiological space of the language, Ph.D. thesis in Philosophical Sciences. Rostov-on-Don: SFU], 2012. 189 p. (in Russian).

5. Adzhemian M., Petrova $Y u$. Features of cultural and religious traditions of the Armenia people. Science almanac of Black Sea region countries. 2020. No. 3. Available at: https://science-almanac.ru/documents/336/2020-03-13Adzhemian.pdf. (accessed 29 December 2020).

6. Leach, E., Lévi-Strauss, Cl. Modern Masters, London: Fontana, 1970. 127 p.

7. Lévi-Strauss $\mathrm{Cl}$. The Raw and the Cooked. Introduction to a Science of Mythology Volume 1, by Jonathan Cape, London. 1970. 387 p.

8. Manjapane F. Feast with a Stranger. Semiotics of Culinary Film, World Congress of Semiotics Sofia. September, New Bulgarian University, 2014, pp. 16-20.

9. Ostapuschenko A., Petrova Yu. Hospitality of the peoples of the North Caucasus as one of the North Caucasus as one of the elements of ethic culture. Science almanac of Black Sea region countries. 2019. No. 4 (20). pp. 22-28.

10. Stano S. Semiotics of Food. In: Trifonas P. (eds) International Handbook of Semiotics. Springer, Dordrecht, 2015. Available at: https://doi.org/10.1007/978-94017-9404-6_30. (accessed 28 December 2020).

11. Folk Costume \& Embroidery, posted by Roman K. Available at: https://folkcostume.blogspot.com/, December 19, 2020. (accessed 28 December 2020).

12. Bulgaria's folk dress is more than a beautiful garment. It displays personal history, posted by Aleksandrova D. Available at: https://matadornetwork.com/read/bulgarian-folk-dress/, Jul 28, 2020. (accessed 19 December 2020).

13. The 10 Best Festivals in Macedonia, posted by The Culture Trip Ltd. Available at: https://theculturetrip.com/. (accessed 23 December 2020). 